\title{
Sedimentology of Arctic Fiords Experiment (SAFE): Project Introduction ${ }^{1}$
}

\author{
J.P.M. SYVITSKI ${ }^{2}$ and C.T. SCHAFER ${ }^{2}$
}

\begin{abstract}
The Geological Survey of Canada's project SAFE (Sedimentology of Arctic Fiords Experiment) was initiated in 1981 and is being carried out in a series of fiords situated along the east coast of Baffin Island. SAFE emphasizes the study of the Quaternary history and modern processes of arctic fiord environments. Project participants are interested in evaluating the significance of the comparatively rapid process rates and of the highresolution sedimentary records that typify these settings.

The key objectives of SAFE include: 1 . To understand sandur development and the character of the resultant facies. 2 . To understand the timedependent influences of rivers, tides, waves, wind and deep-water renewal on fiord circulation and sedimentation patterns. 3. To use the geological record of raised marine deposits in establishing late Quaternary history within and between fiords.

Following a reconnaissance of 10 fiords along the east coast of Baffin Island in 1982, 3 were selected for detailed study during the 1983 field season (Cambridge, Itirbilung, McBeth). The 1982 and 1983 investigations utilized the oceanographic research vessel CSS Hudson as an operations base. During both surveys, core sampling, CTD profiling, geophysical mapping and other heavy work were carried out from the Hudson up to the $100 \mathrm{~m}$ isobath. The shallow water operation was supported by two launches outfitted with equipment to carry the oceanographic and geological programs into nearshore uncharted areas. Field parties were landed to study raised marine deposits and glacial features. The 1983 survey was preceded by a helicopter-supported program that succeeded in mooring and recovering several strings of current meters and sediment traps near the heads of Cambridge and ltirbilung fiords.
\end{abstract}

Key words: sediments, Quaternary, fiord, arctic, Baffin Island, inner shelf

RÉSUMÉ. Le projet RSFA (Recherche sédimentologique sur les fjords de l'Arctique) de la Commission géologique du Canada fut entrepris en 1981 et se poursuit dans une suite de fjords sur le côte orientale de l'île de Baffin. La RSFA met en relief l'étude de l'histoire quaternaire et des processus modernes des milieux de fjords arctiques. Les participants au projet s'intéressent à l'évaluation de l'importance des taux des processus comparativement rapides et aussi aux profils sédimentaires à haute résolution typiques de ces milieux.

La RSFA comprend parmi ses objectifs principaux la compréhension du développement de "sandur" et du caractère des facies qui en résultent; la compréhension des influences temporellement controlées des rivières, des marées, des vagues, des vents et du renouveau en eau profonde sur la sédimentation et la circulation dans les fjords; et l'utilisation du dossier géologique sur les sédiments marins élevés afin d'établir l'histoire du Quaternaire supérieur dans les fjords.

Suite à la reconnaissance de dix fjors sur la côte est de l'île de Baffin en 1982, trois fjords furent choisis pour une étude approfondie au cours de la saison de travail sur le terrain de 1982 (Cambridge, Itirbilung, McBeth). Les études effectuées en 1982 et 1983 firent usage du vaisseau de recherche océanographique CSS Hudson comme centre des opérations. Au cours des deux levés, le carotage, le profilage au CTD et le dressage de cartes géophysiques et d'autres gros travaux furent entreprise à partir du Hudson jusqu'à l'isobathe de $100 \mathrm{~m}$. Les travaux en eaux peu profondes furent exécutés à bord de deux bateaux équipés de sorte à poursuivre les programmes océanographiques et géologiques en des régions non étudiées près du littoral. Des équipes de travail furent postées sur terre afin d'étudier les sédiments marins élevés et les caractéristiques des glaces. Le levé de 1983 fut précédé par un programme complété à l'aide d'un hélicoptère, plaçant et récupérant plusieurs lignes de compteurs de courant et de pièges de sédiments près de l'entrée des fjords Cambridge et Itirbilung.

Mots clés: sédiments, Quaternaire, fjord, Arctique, île de Baffin, zone interne du plateau continental

Traduit pour le journal par Maurice Guibord.

\section{INTRODUCTION}

Fiords are deep, glacially modified estuaries common to highlatitude mountainous coastlines including North and South America, Europe, Greenland, U.S.S.R., Spitsbergen, Iceland, New Zealand, and South Georgia. They are considered to be environmentally sensitive estuaries because of their slow flushing times, a feature unique to fiords (Syvitski and Skei, 1983) and which is among the more important requisite conditions for anthropogenic waste disposal (Skei, 1981). Fiords also command attention for their intrinsic scientific identity: process rates are fast and environmental gradients are large. Attempts at modelling these natural processes in the field often point to fiords as ideal extensions of the scientists' laboratory flumes. (Hay et al., 1983). Fiord deposits have a good potential for providing a comparatively high-resolution sedimentary record that reflects local terrestrial and marine processes (Schafer et al., 1983).
Arctic fiords can be defined as those geomorphological features subject to periglacial processes on land and influenced by the presence of sea ice through at least part of the year (Gilbert, 1983). In Canada, these criteria can be applied to fiords of the eastern arctic archipelago from Ellesmere Island to Baffin Island. Studies of the oceanography and circulation characteristics of arctic fiords have been reviewed by Lake and Walker (1976). The results of the first long-term measurements of currents and circulation characteristics in an arctic fiord are described by Lewis and Perkin (1982). Reconnaissance studies of arctic fiord sediments include the work of Buckley (1971), Bornhold (1976), Berthois (1969), Boulton (1982), Elverhoi et al. (1980), Gilbert (1978, 1980, 1982), Herman et al. (1972), Knight (1971), Lewis et al. (1977), and Prior et al. (1981). Their contributions to our overall understanding of fiord sedimentology have been reviewed recently by Gilbert (1983).

\footnotetext{
${ }^{1}$ SAFE contribution number 1.

${ }^{2}$ Geological Survey of Canada, Bedford Institute of Oceanography, Box 1006, Dartmouth, Nova Scotia, Canada B2Y 4A2
} 
Complex logistic support requirements and an inhospitable climate have made detailed studies of arctic fiords difficult. Knowledge of the nature of these systems is therefore still fragmentary and highly qualitative. Because of an awareness of these shortcomings, the Geological Survey of Canada, in concert with scientists at several universities, initiated a multidisciplinary project to investigate arctic fiords. The project began with some 30 fiord experts from nine universities across five countries and three Canadian federal government departments. Project SAFE (Sedimentology of Arctic Fiords Experiment) began in 1982. By way of this paper, we introduce the project objectives, strategies and field approach as a prelude to future SAFE research manuscripts that will appear in Arctic.

\section{OBJECTIVES}

The present conceptual model (Fig. 1) of the interaction of the processes that drive or inhibit arctic fiord circulation and thus modulate sediment erosion, transport and deposition follows that of Gilbert (1983). Salient features include: 1) the effects of a lengthy presence of sea ice on water stratification; 2) flood-dominated fluvial discharge events occurring within a short runoff season; 3 ) the importance of the Coriolis force on circulation; 4) the breakup of surface stratification during the open-water season through high-energy wind mixing; and 5) the influence of tidewater glaciers on proximal turbulence and sediment deposition. Our objectives were founded upon the following insights specific to arctic fiord sedimentology: 1) the bulk of fluvial-sediment transport can occur within a few days (Church, 1972); 2) extreme winds and lack of vegetation promote large-scale aeolian transport, limited only by the availability of finer-grained material (Gilbert, 1983); 3) sideentry glacial, glaciofluvial and fluvial input of sediment can be substantial (Østrem et al., 1967); 4) rock falls, slides and dirty avalanches are commonly released along the walls of arctic fiords in association with the hydro-fracturing process and can contribute significantly to the coarse fraction of the marine sediment (Church et al., 1979); 5) there are excellent ex-

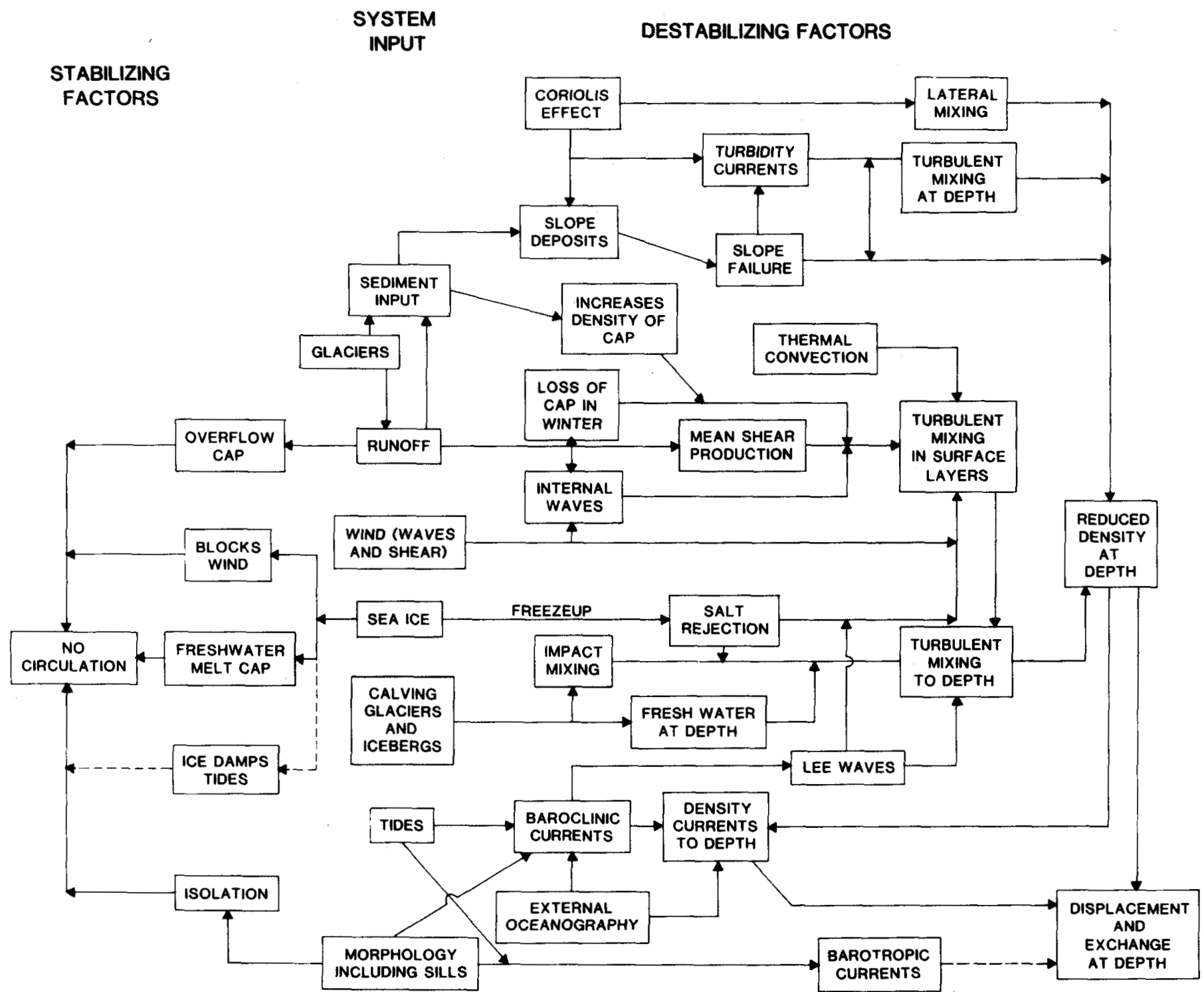

FIG. 1. Conceptual model of the interaction of the factors and processes that drive or inhibit circulation in arctic fiord waters (after Gilbert, 1983). 
posures of isostatically-raised glaciomarine and fluviodeltaic terraces (Andrews, 1978); 6) the dynamics of tidewater glaciers are important modifiers of the stratigraphy within fiords (Powell, 1981; Elverhoi et al., 1980); and 7) the low concentrations and glacier-influenced distribution patterns of organic material and inorganic nutrients have important ecological implications (Pearson et al., 1985). Taken together, this suite of natural phenomena provides a broad perspective on the dominant geological, oceanographic and climatological processes operating within arctic fiords. The key objective of SAFE is to bring together the elements of an interdisciplinary team that can evaluate the links between these processes from a comprehensive point of view. In formulating project goals, emphasis was placed on the Quaternary history of these inlets and on the establishment of a historical baseline to which modern processes can be compared.

The questions being addressed by the geologists involve problems related to variations in annual river discharge and their relationship to sediment flux, fiord turbidity, resuspension events, and to the formation and breakup of sea ice. Oceanographers are contributing to the project through their evaluation of the time-dependent influences on sediment deposition of tides, wave activity, and deep water renewal in relation to overall fiord circulation patterns. They have placed specific emphasis on seiche events, internal wave activity on prodelta slopes and polynya dynamics.

Another goal of SAFE is to utilize real time observations as inputs to sediment transport models. The monitoring data can also be used to calibrate the relationship between proxy climatological and paleoecological signals, contained in welldated marine sediment cores. The distribution of modern endmember assemblages will contribute to the interpretation of Pleistocene sediments that contain similar assemblages. Data for models are selected to reflect the spectrum of key environmental conditions presumed to have existed within these fiords at some time over the past 100000 years.

The Quaternary program was developed to investigate the late Foxe and neo-glacial extent of glaciers in the fiords and their effect on sedimentological processes. In particular, the history of glaciation between 10000 and $40000 \mathrm{BP}$ is currently unknown (J.T. Andrews, pers. comm. 1984).

The geochemical program will focus on the identification and preservation potential of redox discontinuity zones within the sea floor. Redox reactions involving degradation of organic matter may be retarded in arctic fiords, as compared with subarctic or temperate fiords, because of the generally low concentrations of land-derived organic debris. It is also expected that the intermittent pulses of sediment emanating from meltwater rivers or tidewater glaciers may cause wide variations in geochemical reactions.

The geotechnical program was initiated to relate the salient sedimentological and geotechnical properties of the sea floor sediments to the wide variety of slope-dominated environments contained within the fiords. In particular, details of the facies relationships between the many forms of mass movement and sediment gravity flow deposits will be investigated.

\section{FIORD SELECTION STRATEGY}

The most important selection criterion used to identify Canadian fiords for this study was the open-water interval for research ship-based sampling and surveying, our primary field method. High arctic fiords, such as the Nansen Sound-Greely Fiord system of Ellesmere Island, were not considered because of their short open-water season ( $\approx 15$ days). Project SAFE, then, was constrained almost from its inception to fiords situated along the $2000 \mathrm{~km}$ long eastern coastline of Baffin Island (Fig. 2). The island spans a wide range of climatic, geomorphic and oceanographic end members and is characterized further by a relatively long open-water (sea-going) season ( $\approx 45$ days).

The second selection criterion was to have some prior information on the bathymetry within the fiords so that: 1) ship time could be spent primarily on scientific investigations rather than basic hydrography and 2) there would be some prior knowledge of basin and sill depths, a prerequisite for ocean exchange predictions (Stigebrandt, 1981). Of the approximately 290 fiords incising the eastern coast of Baffin Island, only $40+$ had been sounded previously. Of these, most had little more than a couple of axial lines surveyed by the Canadian Coast Guard ship D'Iberville in 1965 and 1966. Exceptions included the moderately detailed surveys of: 1) DEW line stations (e.g., Sunneshine and Ekalugad fiords); 2) those with settlements (e.g., Strathcona Sound, Pond Inlet, Pangnirtung Fiord); and 3) those covered in the surveys of Knight (1971) and Gilbert (1980), i.e., Ekalugad, Maktak, Coronation and North Pangnirtung fiords.

Ten fiords were investigated in 1982 (Fig. 2, Table 1). Their even distribution along the Baffin coast ensured the traverse of a number of important strategic gradients (Maxwell, 1980). These include: 1) a rapid northerly decrease in tidal range $(7 \mathrm{~m}$ to $1 \mathrm{~m}) ; 2$ ) a northerly decrease in ice free days $(60$ to 30$) ; 3)$ a northerly decrease in the active layer above permafrost $(85 \mathrm{~cm}$ to $25 \mathrm{~cm}$ ); 4) a northerly increase in June mean daily global solar radiation from $<500$ langleys $\cdot$ day $^{-1}$ at Frobisher to $>575 \mathrm{ly} \cdot \mathrm{d}^{-1}$ at Pond Inlet; 5) a northerly decrease in mean annual runoff (Fig. 3; $300 \mathrm{~mm}$ to $125 \mathrm{~mm}$ ); 6) a northerly decrease in mean annual temperature (Fig. 3 ); $-7.5^{\circ} \mathrm{C}$ to $\left.-13^{\circ} \mathrm{C}\right)$; 7) a northerly decrease in the mean annual totals of growing degree-days (100 to 40$) ; 8$ ) a northerly decrease in the mean total rainfall ( $200 \mathrm{~mm}$ to $75 \mathrm{~mm})$; and 9) a northerly decrease in mean total snowfall $(600 \mathrm{~cm}$ to $100 \mathrm{~cm})$. In addition, the fiords that were selected provide a wide range of: 1) fiord-head drainage basins (e.g., the McBeth basin is $\approx 20$ times larger than the Sunneshine basin); 2) ice dominance in the fiord-head hinterland (e.g., 3\% in Cambridge, compared to $80 \%$ in Coronation); 3) river valley gradients and thus bed load competence; 4) fiord morphology (sill and basin depths, fiord lengths and widths); and 5) complexities in side-entry (tributary) glaciers and glacial streams. The final choice was also based on predicted sedimentation levels in the fiords estimated from the size of the active sandur surfaces (air photos) and from the size of the fiord surface suspended sediment plume (landsat infra-red images). 


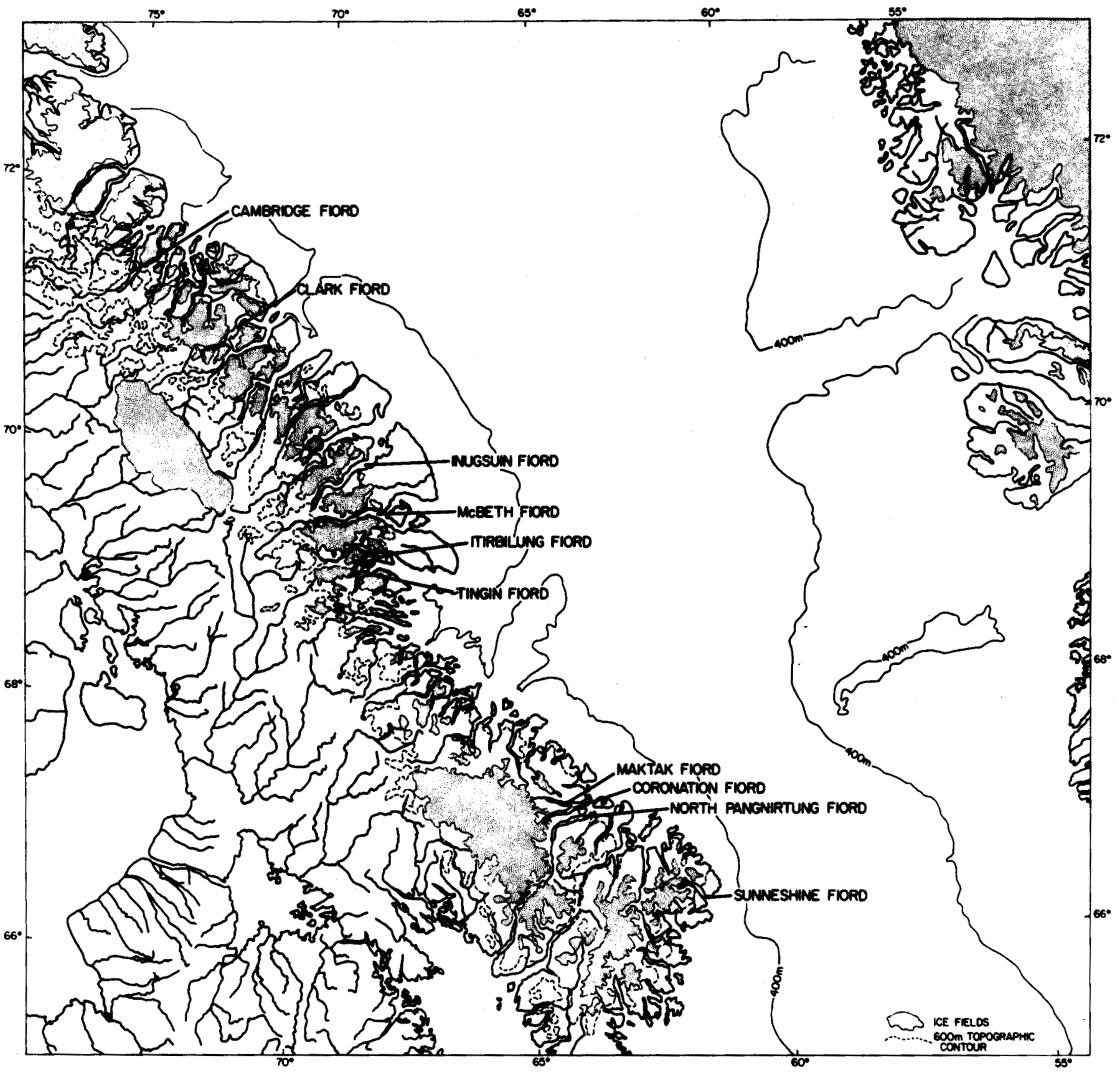

FIG. 2. Ten fiords studied along the NE Baffin Island Coast during project SAFE.

Baffin Island is large, the third largest island on earth with a surveyed area of $507451 \mathrm{~km}^{2}$, of which $35890 \mathrm{~km}^{2}$ is ice covered. The mountainous zone contains all the major ice fields and glaciers with the exception of the Barnes Ice Cap (Fig. 2). The fiords first dissect the Baffin Coastal Lowlands and extend landward into the Davis Highlands, a rugged PreCambrian terrain with peak elevations considerably higher along the flanks of the fiords compared to adjacent inland areas (exceptions are the Cumberland Peninsula fiords) (Fig. 4). The Davis Highlands range in elevation from 1000 to 2000 $\mathrm{m}$ and have a maximum elevation of $2300 \mathrm{~m}$. The Baffin fiords fall within zones of rock desert vegetation and arctic stony lichen and heath. The duration of winter along the fiord coast (i.e., mean number of days with mean daily temperature below $0^{\circ} \mathrm{C}$ ) is 280 days $\left(9 \frac{1}{2}\right.$ months). In general, Baffin fiords are relatively colder than west Greenland fiords.

\section{FIELD STRATEGIES AND METHODS}

The SAFE program consists of three field seasons of intensive sampling and surveying (1982, 1983 and 1985). Details of the 1982 and 1983 field seasons can be found elsewhere (Syvitski, 1982; Syvitski and Blakeney, 1983; Asprey and Johnston, 1984; and Syvitski, 1984). In general, the field 
operations reflect four distinct logistic strategies. The large research vessel CSS Hudson was used primarily for heavy sampling and offshore geophysical survey work. Additionally, Hudson provided an operations centre in each of the fiords for two 9-metre launches and two 5-metre Boston Whaler outboard motor boats. The smaller vessels were deployed daily from the mother ship to conduct shallow water $(<100 \mathrm{~m})$ surveys and to transport work parties to various points of in- terest along the fiord shoreline. A helicopter was used to install monitoring instrumentation near the head of Itirbiling and Cambridge fiords and to carry out sedimentological surveying and sampling over a range of geological settings.

Operations on Hudson during the 1982 and 1983 surveys can be classified into four major categories: sampling, geophysical surveying, data processing, and general logistic support. These activities involved a ship crew of about 70 and 26

TABLE 1. Characteristics of fiords surveyed in the 1982 and 1983 SAFE expeditions

\begin{tabular}{|c|c|c|c|c|c|c|c|c|c|c|}
\hline \multirow[b]{2}{*}{ Fiord } & \multirow{2}{*}{$\begin{array}{l}\approx \text { Ice Free } \\
\text { Days }\end{array}$} & \multicolumn{2}{|c|}{ Tides (m) } & \multirow{2}{*}{$\begin{array}{l}\text { No. of Sills ( ) } \\
\text { and Depth (m) }\end{array}$} & \multirow{2}{*}{$\begin{array}{c}\text { Fiord } \\
\text { Length } \\
(\mathrm{km})\end{array}$} & \multirow{2}{*}{$\begin{array}{c}\text { Mean } \\
\text { Width } \\
(\mathrm{km})\end{array}$} & \multirow{2}{*}{$\begin{array}{c}\text { Max } \\
\text { Depth } \\
\text { (m) }\end{array}$} & \multicolumn{3}{|c|}{$\begin{array}{l}\text { Fiord-head Drainage Basin } \\
\text { Avg. Valley }\end{array}$} \\
\hline & & Average & Large & & & & & Area $\left(\mathrm{km}^{2}\right)$ & $\%$ Ice & Slope \\
\hline Pangnirtung1 & 60 & 5.1 & 7.3 & $(1): 15$ & 43 & 3.1 & 180 & 556 & 53 & .007 \\
\hline N. Pangnirtung & 60 & 0.9 & 1.4 & none & 45 & 3.5 & 480 & 1329 & 57 & .005 \\
\hline Coronation & 60 & 0.9 & 1.4 & none & 30 & 3.2 & 606 & 850 & 80 & .005 \\
\hline Maktak & 60 & 0.9 & 1.4 & none & 65 & 2.3 & 320 & 898 & 53 & .005 \\
\hline Tingin & 50 & 0.8 & 1.1 & $(1): 180$ & $56+$ & 4.6 & 520 & 298 & 20 & .031 \\
\hline Inugsuin & 35 & 1.0 & $?$ & (3) $: 120,380,220$ & 92 & 5.7 & 630 & 220 & 5 & .014 \\
\hline Clark & 30 & 1.0 & 1.3 & (2): 108,185 & 110 & Var. & 760 & 171 & 26 & .053 \\
\hline Cambridge & 30 & 1.0 & 1.4 & (3): $106,230,330$ & 160 & 3.6 & 708 & 584 & 3 & .005 \\
\hline
\end{tabular}

'Pangnirtung is included in the table as an originally selected fiord; however, heavy ice conditions did not permit access to this system and Sunneshine Fiord was substituted.

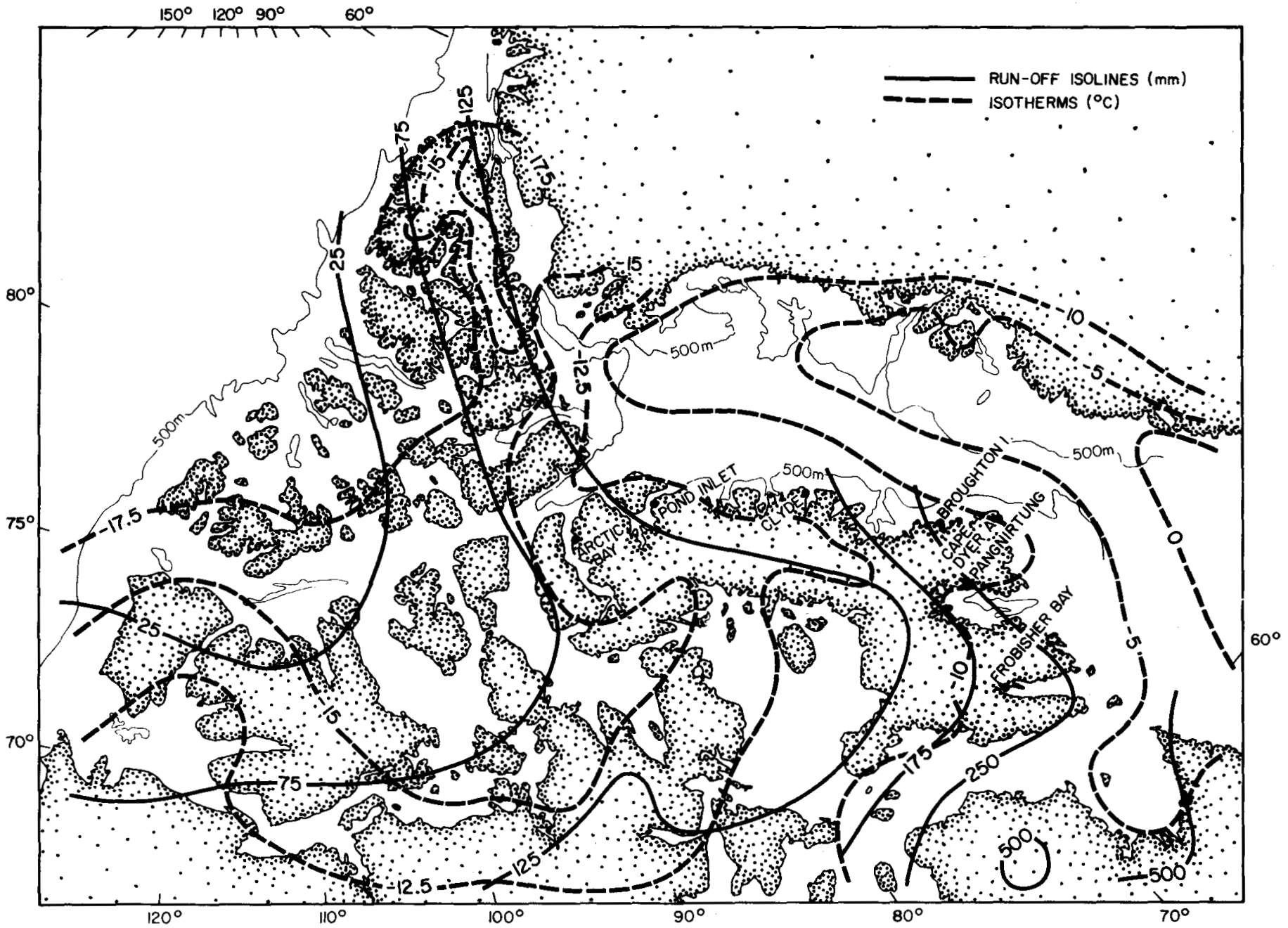

FIG. 3. Mean annual run-off isolines and mean annuai isotherms for the eastern Arctic. 


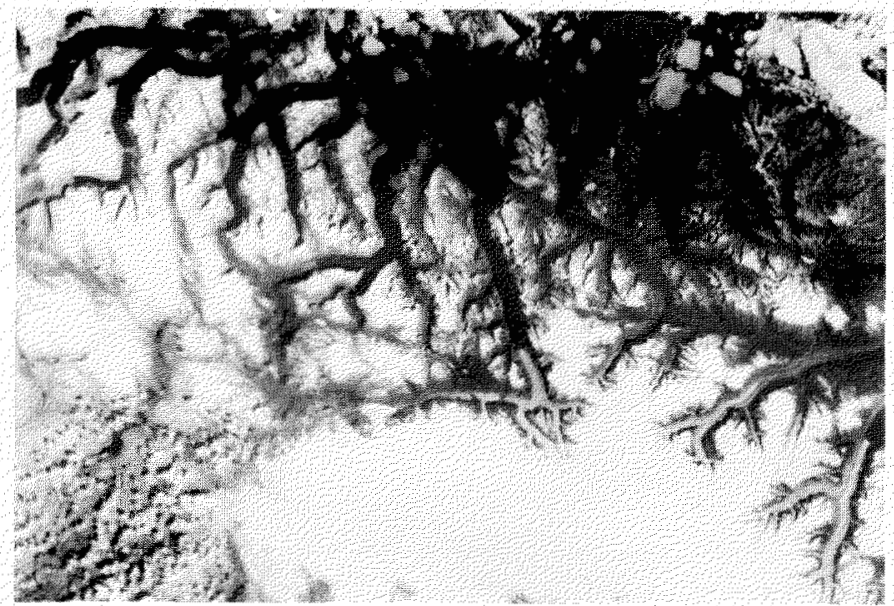

FIG. 4. Landsat (ERTS) 2 (composite from bands 4,5,7) taken on 14 August 1979 showing glaciers that flow into fiords north of the Penny Ice Cap. Farther to the north, sea ice can be seen blocking the mouths of the fiords. Also note the turbid sediment plumes that lead from the head of some of the fiords.

scientific staff operating on a round-the-clock basis. Collecting and sampling activities included surficial sediment grab sampling (VanVeen and Shipek samplers), vertical plankton hauls (200 and $63 \mu \mathrm{m}$ mesh netting), bottom stereo photography, and piston coring. State-of-the-art sampling included a prototype three-barrelled Lehigh gravity corer and a CTD/attenuance meter/rosette water sampler combination sensor package.

Geophysical surveying of offshore sediment deposits and associated morphological features included typically a Huntec high frequency seismic (boomer) system, a Huntec low frequency boomer and Klein side-scan sonar combination sensor, an AGC side-scan SONAR, and a $655 \mathrm{~cm}^{3}$ air gun with its associated seismic hydrophone array. Magnetometer sensors and a Datasonics acoustic profiler were towed occasionally to analyze the magnetic structure of the sea floor and to characterize the structure of fiord water masses respectively. On board laboratory activities emphasized work on Lehigh gravity cores (geochemical and electrochemical analysis) and water analyses (filtering to extract suspended particulate matter, filtering for isotopic chemistry, filtering for bacterial activity, and titration for dissolved oxygen). A number of the staff were responsible for the computer processing of CTD-attenuance profiles and geophysical data. Other personnel using microcomputer data storage systems were charged with the documentation of field activities and related data for both the offshore and inshore surveys. The information was stored on floppy disk files and used subsequently to provide a comprehensive field report for all senior scientific staff during the final days of the cruise.

Each of the two launches was equipped to carry out survey and sampling work especially in uncharted nearshore environments. The hydrographic launch used RADAR fixing and a wide-beam echo sounder to measure water depths across the axis of each fiord. This launch was also set up to collect sediment samples and to deploy a "Dart" unmanned cablecontrolled submersible. The second launch was equipped with a Klein side-scan sonar, a high frequency acoustic profiler, a portable CTD, water and grab samplers. Profiling concentrated on fiord-head prodelta and side-entry glacier localities. Both launches were used to aid in the recovery of current meter-sediment trap moorings deployed several weeks earlier by helicopter.

Two Boston Whalers ferried shore parties to and from the Hudson and carried out light grab sampling tasks in shallow $(<50 \mathrm{~m})$ subtidal environments. The Whalers also provided ice-breaking support for the launches during mooring recovery operations. One land party concentrated its efforts on glacial and fluvial-marine sediment transport processes primarily in fiord head delta areas. A second group of geologists investigated the dynamics of glacier retreat using facies mapping and lichenometry dating techniques. Specialized sampling programs were carried out to evaluate the placer potential of heavy mineral deposits in delta, prodelta and beach environments and magnetic susceptibility of fiord sediments. The information derived from these samples was supplemented by data obtained with a prototype magnetic particle trap moored offshore using helicopter support.

The third and final phase of project SAFE has been planned for September 1985. It will involve a combination of helicopter-transported shore parties and the research vessel M/V Pandora II; the Pandora also supports the manned submersible Pisces IV (for submersible capabilities see Syvitski et al., 1983) which is being used to investigate geomorphological features observed on side-scan SONAR records during the 1982 and 1983 surveys. It is hoped that an outgrowth of SAFE's multidisciplinary approach will continue in the future through the efforts of university participants. Interested researchers should contact Dr. R. Gilbert (Department of Geography, Queen's University, Kingston, Ontario, Canada K7L 3N6), who has been selected by a committee of SAFE participants to coordinate such future research.

\section{ACKNOWLEDGEMENTS}

The initial success of project SAFE is due largely to the cooperation of the following principal investigators and their support staff and students: R.W. Trites, physical oceanography, with W.M. Petrie (Marine Ecology Laboratory, Fisheries and Oceans, Canada); A.E. Hay, physical oceanography, with B. DeYoung, J. Foley, S. Macko, and M. Emery-Moore (C-Core and Depts. Biology, Physics, Geology, Memorial University); R. Belanger, R. Currie, K.M. Ellis, and J.N. Smith, radioisotopes (Atlantic Oceanographic Laboratory, Fisheries and Oceans, Canada); L.J. Albright, bacteriology, and E.M.D. Stroh (Dept. Biology, Simon Fraser University); G.E. Farrow, macrobenthos (Department of Geology, University of Glasgow); F.J. Hein, geotechnical properties, F.J. Longstaffe, mineralogy, and M. Reasoner (Department of Geology, University of Alberta); J.H. Kravitz, geotechnical properties (U.S. National Oceanographic and Atmospheric Administration); J.T. Andrews Quaternary dynamics, with A. Jennings, L. Osterman, J. Stravers and K. Williams (Institute of Arctic Alpine Research, University of Colorado), J.S. Mothersill, paleomagnetics (Department of Geology, Lakehead University); R. Gilbert, sedimentology (Department of Geography, Queen's University); G. Bika (Huntec Ltd.); J. Banner and K.U. Weyer, hydrogeology (National Hydrology Research Institute, Inland Waters Directorate); G.D. Hodge (Department of Geological Sciences, University of British Columbia); M. Lamplugh and G. Rodgers (Canadian Hydrographic Service, Department of Fisheries and 
Oceans); G.S. Boulton and J. VanderMeer, Quaternary facies (Department of Environmental Sciences, University of East Anglia and University of Amsterdam); W.N. Catchpaugh, D. Silvester and Cmdr. B. Martin (Fleet Diving Unit, Atlantic, Department of National Defense); K.W. Asprey, T. Atkinson, P. Bishop, C.P. Blakeney, A. Boyce, F.E. Cole, D. Clattenburg, L. Johnston, R.A. Fitzgerald, B. Kelly, W. Leblanc, B. MacLean, Baffin shelf stratigraphy, P.J. Muide, palynology, R. Murphy, J. Nielsen, M.A. Rashid, organic geochemistry, K.R. Robertson, R.B. Taylor, coastal dynamics (Atlantic Geoscience Centre, Geological Survey of Canada). Our appreciation is also extended to Captain F. Mauger of the CSS Hudson and his officers and crew who provided support beyond the call of duty.

\section{REFERENCES}

ANDREWS, J.T. 1978. Sea level history of arctic coasts during the Upper Quaternary; dating sedimentary sequences, and history. Progress in Physical Geography 2:375-407.

ASPREY, K.W., and JOHNSTON, L. 1984. Report on CSS HUDSON cruise 83-028, Baffin Island Fjords. Geological Survey of Canada, openfile $1004.189 \mathrm{p}$.

BERTHOIS, L. 1969. Contribution a l'etude sedimentologique du Kangerdlugssuag, cote ouest du Groenland. Medd. Gronland 187 (1). 118 p.

BORNHOLD, B.D. 1976. Marine surficial geology: central and eastern Arctic. Geological Survey of Canada, paper 76-1A. 29-31.

BOULTON, G.S. 1982. Glaciomarine environments and sedimentation. IAS Eleventh International Congress on Sedimentology. Abstracts. 74.

BUCKLEY, D.E. 1971. Recent marine sediments of Lancaster Sound, District of Franklin. Maritime Sediments 7:96-117.

CHURCH, M. 1972. Baffin Island sandurs: a study of arctic fluvial processes. Geological Survey of Canada, Bull. 26. 208 p.

, STOCK, R.F., and RYDER, J.M. 1979. Contemporary sedimentary environments on Baffin Island, N.W.T., Canada: debris slope accumulations. Arctic and Alpine Research 11:371-402.

ELVERHOI, A., LIESTOL, O., and NAGY, J. 1980. Glacial erosion, sedimentation and microfauna in the inner part of Kongsfjorden, Spitsbergen. Saertrykk au Norsk Polarinstitutt, Skrifter rir. 172:33-61.

GILBERT, R. 1978. Observations on oceanography and sedimentation at Pangnirtung Fjord, Baffin Island. Maritime Sediments 14:1-9.

1980. (Unpub. ms.) Environmental studies in Maktak, Coronation and North Pangnirtung Fiords, Baffin Island, N.W.T. Final report of research supported by Petro Canada Exploration Inc., NSERC and Dept. of Geology, Queen's University, Kingston, Ontario. 97 p.

1982. Contemporary sedimentary environments on Baffin Island, N.W.T., Canada: Glaciomarine processes in fiords of eastern Cumberland Peninsula. Arctic and Alpine Research 14:1-12.

1983. Sedimentary processes of Canadian arctic fiords. Sedimentary Geology 36:147-175.
HAY, A.E., MURRAY, J.W., and BURLING, R.W. 1983. Submarine channels in Rupert Inlet, British Columbia: I. Morphology. Sedimentary Geology 36:289-315.

HERMAN, Y., O'NEIL, J.R., and DRAKE, C.L. 1972. Micropaleontology and paleotemperatures of postglacial SW Greenland fjord cores. In: Vasari, Y., Hyvarinen, H., and Hicks, S., eds. Climatic changes in Arctic Seas during the last 10,000 years. Acta Univ. Ouluensis, Ser. A. Geologica No. 1:359-405.

KNIGHT, R.J. 1971. Distributional trends in the recent marine sediments of Tasiujag Cove of Ekalugad Fjord, Baffin Island, N.W.T., Maritime Sediments 7:1-18.

LAKE, R.A., and WALKER, E.R. 1976. A Canadian arctic fiord with some comparisons to fjords of the western Americas. Journal of the Fisheries Research Board of Canada 33:2272-2285.

LEWIS, C.F.M., BLASCO, S.M., BORNHOLD, B.D., HUNTER, J.A.M., JUDGE, A.S., KER, J.W., MCLAREN, P., and PELLETIER, B.R. 1977. Marine geological and geophysical activities in Lancaster Sound and adjacent fjords. Geological Survey of Canada Paper 77-1A:495-506.

LEWIS, E.L., and PERKIN, R.G. 1982. Seasonal mixing processes in an arctic fiord system. Journal of Physical Oceanography 12:74-83.

MAXWELL, J.B. 1980. The Climate of the Canadian Arctic Islands and Adjacent Waters. Environment Canada AES. 531 p.

DSTREM, G., BRIDGE, C.W., and RANNIE, W.F. 1967. Glacio-hydrology, discharge and sediment transport in the Decade Glacier area, Baffin Island, N.W.T. Geographic Annaler 49A:268-282.

PEARSON, T.H., BURRELL, D.C., and FEDER, G. 1985. Fjords. In: Wolfe, W.J., ed. Coastal Ecology Sourcebook (in press).

POWELL, R.D. 1981. A model for sedimentation by tidewater glaciers. Annals of Glaciology 2:129-134.

PRIOR, D.B., WISEMAN, Jr., W.J., and BRYANT, W.R. 1981. Submarine chutes on the slopes of fjord deltas. Nature 290:326-328.

SCHAFER, C.T., SMITH, J.N., and SEIBERT, G. 1983. Significance of natural and anthropogenic sediment inputs to the Saguenay Fjord, Quebec. Sedimentary Geology 36:177-194.

SKEI, J.M. 1981. The entrapment of pollutants in Norwegian fjord sediments - a beneficial situation for the North Sea. Special Publication, International Association Sedimentologists 5:461-468.

STIGEBRANDT, A. 1981. A mechanism governing the estuarine circulation in deep strongly stratified fjords. Estuarine, Coastal \& Shelf Science 13:197-211.

SYVITSKI, J.P.M. 1982. Cruise Report: C.S.S. HUDSON 82-031. Geological Survey of Canada, Open file report 897. 77 p.

1984. Sedimentology of Arctic Fjords Experiment: HU83-028 data report, Volume 2. Canadian Data Report of Hydrography and Ocean Sciences. No. 28. $1130 \mathrm{p}$.

and BLAKENEY, C.P. 1983. Sedimentology of Arctic Fjords Experiment: HU82-031 data report, volume I. Canadian Data Report of Hydrography and Ocean Sciences. No. 12. 935 p.

SYVITSKI, J.P.M., FADER, G., JOSENHANS, H., and PIPER, D.J.W. 1983. Seabed investigations of the Canadian east coast and Arctic using PISCES IV. Geoscience Canada 10:59-68.

SYVITSKI, J.P.M., and SKEI, J.M., eds. 1983. Sedimentology of Fjords. Sedimentary Geology. Vol. 36:75-342. 